\title{
Transgresja twórcza w procesie rozwoju osobistego
}

\begin{abstract}
Abstrakt
Artykuł i zaprezentowane w nim badania inspirowane są koncepcjami podejmującymi temat transgresyjnego charakteru ludzkiej egzystencji. Autorka podjęła w nim próbę ukazania wielowymiarowości i znaczenia transgresji twórczych w kontekście rozwoju człowieka dorosłego. Artykuł stanowi relację z badań własnych, które prowadzą autorkę do skonstruowania modelu transgresji jako całożyciowego procesu (samo)uczenia się.
\end{abstract}

Słowa kluczowe: transgresja twórcza, rozwój osobisty, transgresje w edukacji.

\section{Creative transgression in the process of personal development}

\begin{abstract}
The article and the research presented in it are inspired by concepts that deal with the subject of the transgressive nature of human existence. The author attempted to present the multidimensionality and meaning of creative transgressions in the context of the development of an adult person. The article is a review of the author's own studies that lead her towards constructing the model of transgression as a life-long process of (self)learning.
\end{abstract}

Keywords: creative transgression, personal development, transgressions in education.

\section{Wprowadzenie}

Niniejszy artykuł i zaprezentowane badania ${ }^{1}$ inspirowane są koncepcjami podejmującymi temat granicznego charakteru ludzkiej egzystencji, a w jej obrębie człowieka jako sprawcy, który swoimi dokonaniami przekracza w sposób twórczy gra-

\footnotetext{
* Uniwersytet Łódzki.

1 Badania prowadzone były w ramach rozprawy doktorskiej pt. Znaczenie zasobów psychospołecznych $w$ dokonywaniu twórczych transgresji pedagogicznych. Studia indywidualnych przypadków beyonders, napisanej pod kierunkiem prof. Krzysztofa J. Szmidta w Katedrze Badań Edukacyjnych Uniwersytetu Łódzkiego w 2015 r.
} 
nice przeciętności. Słowem kluczem wyznaczającym tu sposób rozumienia szeroko pojętej twórczości człowieka jest „granica”, zarówno ta psychologiczna odnosząca się do wewnętrznej natury i subiektywnie spostrzeganych możliwości człowieka, ale także granice zewnętrzne w postaci ustaleń społecznych, poznawczych, geograficznych i wielu innych, które wyznaczają sposób funkcjonowania świata i ludzi. W tym ujęciu twórczość i rozwój człowieka rodzi się w wyniku paradoksu. Z jednej strony człowiek dąży do wyznaczenia granic i ram, które dają mu poczucie rozpoznania całości i bezpieczeństwa, określają zakres jego wiedzy i możliwości. Z drugiej strony, napotykając granice, każdorazowo odczuwa pragnienie ich przekroczenia lub poszerzenia, powodując nieustanne wkraczanie w coś, co jest mu obce.

Tłem filozoficznym dla niniejszych rozważań i zaprezentowanych w dalszej części badań była koncepcja „transcendencji życia” w ujęciu niemieckiego socjologa i filozofa Georga Simmla (1975, 1997, 2006, 2007). Autor uzasadnia w niej, że graniczny charakter ludzkiej egzystencji stanowi punkt wyjścia do najbardziej decydującego sensu życia: „Istnienie granicy jako takiej jest konieczne, ale każda konkretna granica może zarazem zostać przekroczona, każde ustalenie przesunięte, każda bariera rozsądzona; akt przekroczenia ustanawia każdorazowo nową granicę" (Simmel 2007: 16). Jako istotę rozwoju człowieka autor opisuje funkcję zwaną transcendowaniem siebie lub samotranscendencją, która objawia się w postaci naturalnej tendencji do przełamywania ograniczeń natury wewnętrznej - „aktu ogarniania każdorazowo swego Innego" (tamże: 30).

Ramy teoretyczne zaprezentowanych badań wyznacza paradygmat psychotransgresjonizmu i założenia transgresyjnej natury człowieka opisane w licznych publikacjach przez Józefa Kozieleckiego (zob. 1987, 1992, 1996, 1997, 2001, 2004, 2007, 2008, 2009). W wybranym ujęciu człowiek jest układem transgresyjnym, a aktywność transgresyjna stanowi najbardziej charakterystyczną cechę homo sapiens, która nie ma swojego odpowiednika w świecie zwierząt. Transgresja - główny przedmiot zainteresowań w prezentowanym artykule to „zjawisko polegające na tym, że człowiek intencjonalnie wychodzi poza to, co posiada i czym jest" (Kozielecki 1987: 10). Oznacza to, że zarówno w procesie historycznym, jak i ontogenetycznym ludzie przekraczają dotychczasowe granice swoich osiągnięć w różnych postaciach. Mianem działań transgresyjnych Kozielecki określa:

(...) działania ekspansywne, twórcze, ekspresyjne, które przekraczają istniejący stan rzeczy, których wyniki wychodzą poza granice osiągnięć materialnych, poznawczych i społecznych. Wykonując je, człowiek przezwycięża swoje ograniczenia, swoją niedoskonałość i swoją skończoność. Dzięki temu tworzy nowe wartości i realizuje ambitne interesy. Opanowanie przyrody, odkrycia naukowe, wynalazki techniczne, rozwój sztuki, stanowienie prawa, łamanie konwencji, kształcenie swojego charakteru (...), produkcja nowych broni, to nieliczne przykłady takiego sprawstwa (Kozielecki 2009: 333). 
Nawiązując do powyższych inspiracji teoretycznych, chcę wprowadzić Czytelnika w sposób rozumienia rozwoju osobistego człowieka, w którym aktywność transgresyjną uznaję za główny mechanizm odpowiedzialny za dokonujące się w człowieku i wokół niego zmiany. W niniejszych badaniach zajmuję się znaczeniem konstruktywnych zmian, czyli tych, które prowadzą do rozwoju i twórczości.

Artykuł stanowi relację z badań własnych. W pierwszej części przybliżę ich koncepcję, w drugiej zaś zaprezentuję wyniki badań, na podstawie których opisałam model transgresji jako twórczego całożyciowego procesu (samo)uczenia się.

\section{Koncepcja badań}

Wyjściowe kategorie analityczne zaprezentowanych badań opierają się na czteroaspektowym paradygmacie rozumienia zjawisk twórczych i obejmują: osobę sprawcy transgresji, proces doprowadzający do transgresji twórczych, uwarunkowania sprzyjające i utrudniające dokonywanie transgresji oraz wytwory tychże transgresji. Każdy z tych aspektów wyznacza inny obszar badawczy (rysunek 1):

UWARUNKOWANIA

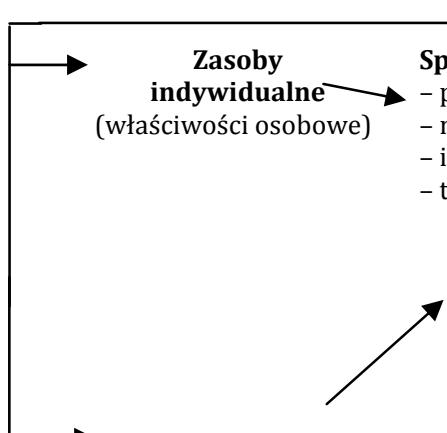

OSOBA Sprawca transgresji:

- pedagog

nauczycie

- innowator

- twórca
PROCES

Dynamika
transgresji:
- strategie,
heurystyki twórcze
- etapy działania
- udział osobistych
zasobów
- rola transgresji
w biografii osoby
- motywacja

Granice:

- wewnętrzne /

osobowe

- zewnętrzne /

środowiskowe

- świadomość

granic

i wartości

- tożsamość

- duchowość

Technika badawcza:

kwestionariusz, wywiad
Technika badawcza:
wywiad

Technika badawcza: wywiad

WYTWÓR

Transgresja pedagogiczna:

- psychologiczna

- innowacyjna

- twórcza

konstruktywna

- jednostkowa
Przejawy transgresji: - obiektywne dokonania - subiektywne dokonania

Technika badawcza: wywiad, analiza dokumentów

Rys. 1. Ramy pojęciowe przyjęte w badaniach Źródło: opracowanie własne 
Po pierwsze osoba - określana w badaniach jako transgresjonista i sprawca transgresji (Kozielecki 1997). Zdecydowałam się poznać i zanalizować przejawy transgresyjności w dziedzinie edukacji, w grupie pedagogów i nauczycieli, dla których transgresyjność stała się stylem pracy, którzy wypełniają swoje obowiązki zawodowe w sposób twórczy i innowacyjny na tle skostniałych struktur i procesów edukacyjnych w Polsce (Schulz 1989, 1990, 1994; Dauber 1997; Baranowicz 2000; Figiel 2001; Przyborowska 2003, 2013; Petty 2010). Badani w niniejszej pracy to konkretne osoby znane z imienia i nazwiska. Są to m.in.: założyciele autorskich szkół eksperymentalnych oraz ośrodków innowacji edukacyjnych, twórcy i koordynatorzy innowacyjnych programów edukacyjnych i wychowawczych, liczących się w środowisku pedagogicznym, twórcy podręczników i alternatywnych metod nauczania, twórcy nowych koncepcji naukowych. Ostatecznie grupa badanych liczyła dwanaście osób. Dobrane zostały na podstawie nominacji eksperckiej (Miles, Huberman 2000), przy udziale i rekomendacjach ekspertów z dziedziny edukacji i pedagogiki twórczości. Kierowałam się także opinią publiczną na temat osób oraz ich nowatorskich osiągnięć edukacyjnych, które stanowiły kontrowersyjną i dyskusyjną w społeczności pedagogicznej nowość, wykraczającą poza powszechnie przyjęte standardy. Właśnie tego typu osoby i dokonania były najbardziej pożądane w moich badaniach.

Po drugie proces transgresji i jego uwarunkowania, w tym aspekcie uwagę zwróciłam na: (1) istotę samego zajścia transgresji, polegającą na twórczej konfrontacji z pewną niemożnością osobistą lub barierą zewnętrzną oraz (2) dynamikę procesu radzenia sobie w sytuacji granicznej, charakteryzującej się nowością i wysokim stopniem ryzyka. Założyłam, że transgresja to stan lub zachowanie, które w swej istocie polega na wytrąceniu osoby ze sfery komfortu i stałości, ze względu na niską przewidywalność efektu oraz niemożność odwołania się do podręcznego repertuaru zachowań, znanych i sprawdzonych, wynikających z dotychczasowego doświadczenia życiowego. Proces transgresji rozumiem za Józefem Kozieleckim jako proces rozwojowy osoby, charakteryzujący się nieustającym ruchem od „ja aktualnego” w kierunku ,ja możliwego” (Kozielecki 1997). Perspektywa rozwojowa zakłada, że transgresje zawodowe pedagogów nie mogą być analizowane w oderwaniu od kontekstu życia i biografii sprawcy. To co zawodowe, przenika się z tym, co osobiste, to co publiczne, $\mathrm{z}$ tym, co intymne i nieujawnione, to co namacalne i konkretne z tym, co abstrakcyjne i trudne do uchwycenia.

Po trzecie wytwór - rozumiany jako wynik procesu i praktyczne przejawy aktywności transgresyjnej. Jednym z powodów podjętych przeze mnie badań było poznanie i spotkania $\mathrm{z}$ osobami, które $\mathrm{w}$ swoich działaniach pedagogicznych przekraczają twórczo granice i wychodzą poza szablonowe schematy i rozwiązania edukacyjne. Wiele $\mathrm{z}$ twórczych transgresji pedagogicznych nie przekracza terenu szkoły i obszaru osobistych refleksji nauczycieli/pedagogów lub nie przechodzi przez proces konwencjonalizacji społecznej. Ja miałam szczęście rozmawiać z osobami, którym udało się zrealizować swoje odważne pomysły i wizje transgresyjne. 
Stąd istotne staje się pytanie o miejsce i znaczenie dokonań transgresyjnych w polskim systemie edukacji.

Główną kategorią badawczą w prezentowanych badaniach są transgresje psychologiczne mające znaczenie w wymiarze życia osobistego i zawodowego osoby oraz jej otoczenia społecznego, nie zaś dokonania historyczne i wybitne. W obrębie tej grupy wybrałam transgresje twórcze, czyli polegające na generowaniu wartościowej nowości, w postaci nowych idei, pomysłów i rozwiązań o charakterze systemowym, teoretycznym i dydaktycznym w dziedzinie edukacji, oraz transgresje innowacyjne polegające na przełożeniu tych twórczych idei na język praktyki pedagogicznej, czyli wdrażaniu ich w postaci gotowych produktów bądź procedur. Warto nadmienić, że w naukach humanistycznych o twórczym i innowacyjnym charakterze działań można mówić tylko w odniesieniu do transgresji konstruktywnych, czyli takich, które niosą ze sobą dobra i wartości w wymiarze społecznym (Szmidt 2013). W niniejszej pracy nie brałam pod uwagę transgresji destruktywnych, choć zaznaczyć należy, że czasem trudno jest przewidzieć, do czego proces transgresyjny w ostateczności doprowadzi.

Jako metodę organizującą tok postępowania badawczego wybrałam studia indywidualnych przypadków ujmowane w sposób wąski, charakterystyczny dla badań pedagogicznych i psychologicznych. Przyjęłam klasyczne rozumienie metody jako badania jednostkowych przypadków ludzkich (por. Kamiński 1970; Turlejska 1998; Łobocki 2006; Konarzewski 2000; Pilch, Bauman 2001; Galewska-Kustra 2009). Przy wyborze rodzaju metody przyjęłam zasady prowadzenia badań z typologii znanych i cenionych w literaturze przedmiotu, opracowanych m.in.: przez: Roberta Stake'a (2009), Roberta K. Yina (1994, 2003) oraz Sharan B. Merriam (1998). Najbliższe niniejszym badaniom jest heurystyczne studium przypadku w ujęciu Merriam, w którym badania mają stanowić rozwinięcie i uzupełnienie teorii, w tym przypadku transgresyjnej koncepcji człowieka, a ich wyniki mają przyczynić się do lepszego zrozumienia dynamiki transgresji twórczych, ze względu na udział zasobów osobistych, procesów i warunków potrzebnych do ich realizacji.

Wiodącą rolę w zbieraniu materiału badawczego przypisano technice wywiadu - w zrozumieniu doświadczeń granicznych/transgresyjnych narratorów w kontekście ich biografii oraz analizie dokumentów stanowiących faktograficzne i kontekstualne tło dla zebranych doświadczeń. Sposób prowadzenia wywiadu powstał z inspiracji jakościowym ujęciem w koncepcji Jeana Claude'a Kaufmanna (2010), który wprowadził pojęcie „wywiad rozumiejący”. Wymienione techniki stanowią o jakościowym wymiarze studium przypadku. Jako narzędzia uzupełniające i weryfikujące tok badań wykorzystałam dwa kwestionariusze testowe: polską Skalę Transgresji Ryszarda Studenskiego $(2004,2006)$ oraz nieznany w badaniach pedagogicznych na gruncie polskim Inwentarz Sił Charakteru VIA-IS (Values in Action - Inventory of Strenghts), autorstwa Christophera Petersona i Martina Seligmana (2004). 


\section{Analiza wyników badań}

Analiza materiału badawczego w postaci: transkrypcji z dwunastu przeprowadzonych wywiadów, zebranych dokumentów i danych faktograficznych oraz danych ilościowych uzyskanych z kwestionariuszy testowych doprowadziła do wyników badań w dwóch częściach.

W części pierwszej transgresyjność została ukazana jako działanie jednostkowe, zindywidualizowane, dziejące się w określonym kontekście, wyznaczonym przez cechy i biografię sprawcy transgresji, który wypracował swój własny repertuar taktyk, strategii i heurystyk transgresyjnych, na miarę swoich doświadczeń życiowych i zawodowych. Na tej podstawie skonstruowano dwanaście portretów transgresjonistów, z których wyłoniono pięć kluczowych, tj. transgresjonistę interakcyjnego, prognostycznego, emancypacyjnego, inkrementalnego i aksjologicznego, z których każdy jest ilustracją zupełnie odmiennego programu działań transgresyjnych (Kozielecki 1987). Każdy z zaprezentowanych portretów stanowi opis mechanizmów ujawniających indywidualną dynamikę dokonywania transgresji.

W części drugiej - przekrojowej przeprowadzono analizę porównawczą w odniesieniu do wszystkich badanych. Podejmowane w tym kroku czynności polegały na porównaniu, stworzonych na poprzednim etapie, portretów transgresyjnych poprzez wyróżnienie wspólnych i kontrastowych kategorii badawczych. W trakcie analizy można było zauważyć, że profile narratorów odzwierciedlają pewną powtarzalność pewnych strategii i procesów transgresyjnych. Na tej podstawie wyłoniono główne linie tematyczne, które scalają wszystkie dwanaście portretów transgresyjnych w postaci typologii obejmującej trzy typy doświadczeń transgresyjnych:

1) Transgresja jako doświadczenie egzystencjalne - „Wyjście ze świata myślanego";

2) Transgresja jako doświadczenie relacyjne - „Spotkanie w różnicy”;

3) Transgresja jako doświadczanie generacyjne - „Realizacja misji przekraczającej jednostkową tożsamość".

W ostatnim kroku dokonano uogólnień teoretycznych na podstawie wszystkich zebranych danych. Otrzymane porównania, podobieństwa i kontrasty stanowiły zasadniczy krok w kierunku stworzenia modelu dynamiki transgresji twórczych. Ukazuje on procesualny charakter transgresji i jej różnicowanie się w zależności od tego, jaką rolę odgrywa ona w biografii sprawcy.

Na potrzeby niniejszego artykułu, w kolejnej części zaprezentowałam ostatni krok z przedstawionej analizy badawczej, czyli model transgresji zawierający najważniejsze wnioski i uogólnienia teoretyczne ${ }^{2}$.

\footnotetext{
2 Czytelników zainteresowanych pełnym opisem wymienionych wyżej wyników badań odsyłam do autorskiej monografii: A. Chmielińska (2017).
} 


\section{Transgresja jako spiralny proces (samo)uczenia się - prezentacja modelu teoretycznego}

W tej części pragnę pokazać, że transgresje, które badałam, mają charakter procesualny i rozwojowy. To znaczy, że typ transgresji różnicuje się w zależności od tego, jaką rolę odgrywa ona $\mathrm{w}$ biografii sprawcy. Różnicowanie się transgresji widzę w postaci spirali, po której poruszamy się do przodu z częstymi powrotami na tę samą ścieżkę. I podobnie badani powracali w swoim życiu kilkukrotnie do tych samych wątków, ale za każdym razem na wyższym poziomie świadomości. Doświadczenia graniczne zdobyte na poprzednich etapach życia zabierali ze sobą do następnych, tzn. że przebytych lekcji nigdy nie zapominamy. Nawet jeżeli doświadczamy ich po raz wtóry, to zawsze z większą świadomością.

W opracowanym modelu (rysunek 1) założyłam, że każdy nowy problem, kryzys lub zmiana życiowa zapoczątkowująca transgresję może przechodzić kolejno przez trzy typy doświadczeń transgresyjnych, tj.: (1) od ugruntowania idei w „świecie myślanym” sprawcy transgresji (transgresja jako doświadczenie egzystencjalne), przez (2) skonfrontowanie jej z otoczeniem (transgresja jako doświadczenie relacyjne), aż do jej (3) upowszechnienia i zapisania siebie w swoich dokonaniach (transgresja jako doświadczenie generacyjne i kontynuacja Ja w następnych pokoleniach). Wymienione trzy typy doświadczeń transgresyjnych zostały wyłonione na podstawie konkretnych kryteriów w trakcie analizy przekrojowej doświadczeń transgresyjnych wszystkich narratorów ${ }^{3}$.

Dodatkowo w ramach analizy przekrojowej u większości narratorów uwidoczniła się tendencja ukazująca podział biografii transgresyjnej na okresy:

(1) wstępny - kształtowanie się orientacji transgresyjnej, czyli postawy ukierunkowanej na przekraczanie granic, przejawiającej się np. jako młodzieńcze pragnienie wyjścia poza dotychczasowy, znany lub stereotypowy stan rzeczy, charakterystyczny dla najbliższego otoczenia (np. własnej rodziny czy grupy rówieśniczej); działania podejmowane w tym czasie nie zawsze były w ujęciu narratorów intencjonalne. Ich istotą jest bardziej działanie na przekór i bycie w opozycji do czegoś niż przemyślane działanie dla własnego dobra. Kształtowanie się orientacji transgresyjnej jest budzeniem się poczucia odmienności i niedopasowania w środowisku rodzinnym lub/i rówieśniczym; niezgodą na to, co proponuje najbliższy świat; niechęcią kontynuacji pewnych wzorców, ale jeszcze bez wiedzy na temat tego, czego się chce i kim chce się być.

(2) okres transgresji przygotowawczych - pierwsze, intencjonalne, udane bądź nie próby przekraczania granic, najczęściej psychologicznych, tj. ograniczeń natury wewnętrznej, dotyczących przekonań na temat siebie i własnych możliwości. Są to transgresje „przepowiadające”, będące niejako zapowiedzią i dojrzewaniem

\footnotetext{
3 Tamże.
} 
w transgresyjności, które ma na celu kształtowanie zasobów osobistych potrzebnych do twórczego przekraczania granic na większą skalę, w konfrontacji z ograniczeniami zewnętrznymi, systemowymi, np. w sferze zawodowej.

(3) okres największej produktywności twórczej, w którym dokonano transgresji kluczowych, tj. takich, z których sprawca transgresji jest znany i rozpoznawany w swoim środowisku (pedagogicznym); można powiedzieć, że są to transgresje dojrzałe - transgresje twórcze i innowacyjne, będące owocem wieloletniej pracy w danej dziedzinie i znajomości danej dziedziny. Często transgresje kluczowe mają charakter „powrotów”, tzn. zachodzą po okresowym odejściu od własnej dziedziny i poznania siebie w zupełnie innym kontekście, na innym polu zawodowym. Cechą charakterystyczną aktywności transgresyjnej w tym okresie jest wewnętrzna integralność i poczucie spójności tego, jak osoba się zachowuje i co robi z tym, co myśli, w co wierzy i kim się czuje.

Biorąc pod uwagę trzy wymienione typy transgresji (transgresja jako doświadczenie egzystencjalne, transgresja jako doświadczenie relacyjne, transgresja jako doświadczenie generacyjne i kontynuacja Ja w następnych pokoleniach) oraz ich podział na: kształtowanie się orientacji transgresyjnej, transgresje przygotowawcze i kluczowe, transgresję rozumiem jako proces (samo)uczenia się w postaci trójwymiarowej spirali (rysunek 2).

Zaprezentowany poniżej model można odczytać na dwa sposoby:

1. W pierwszym z nich transgresję można analizować jako proces, w ramach trzech następujących po sobie cykli transgresji, tj.: Cykl A - transgresja jako doświadczenie egzystencjalne: $1 \mathrm{a}-2 \mathrm{a}-3 \mathrm{a}$, następnie Cykl B - transgresja jako doświadczenie relacyjne: $1 \mathrm{~b}-2 \mathrm{~b}-3 \mathrm{~b}$ oraz Cykl $\mathrm{C}$ - transgresja jako doświadczenie generacyjne: $1 c-2 c-3 c$.

Każdy cykl transgresji uczy czegoś innego i jest związany z odmiennymi problemami, inną naturą przekraczanych granic i innymi poszukiwaniami. Wszystkie trzy cykle razem wzięte ukazują pełnię doświadczenia transgresyjnego i zmieniające się znaczenie transgresji w skali życia sprawcy.

2. Drugi sposób odczytania modelu odnosi się do intensywności i skali transgresji. Ukazuje spiralny proces przejścia na coraz wyższy poziom złożoności transgresji, tj.: poziom pierwszy - okres kształtowania się orientacji transgresyjnej: 1a $1 b-1 c$; poziom drugi - okres transgresji przygotowawczych: $2 a-2 b-2 c$ oraz poziom trzeci - okres transgresji kluczowych: $3 a-3 b-3 c$. W tym ujęciu wszystkie trzy typy transgresji są wzajemnie zależne od siebie i przenikają się, ukazując niejako „dojrzewanie w transgresji”.

Poniżej zamieszczono poszerzony opis modelu według pierwszego z wyżej wymienionych sposobów, dotyczącego kolejności przejścia przez wszystkie trzy cykle. Drugi sposób, dotyczący skali i zaawansowania transgresji można odczytać na przedstawionym diagramie (rysunek 2). Jak wspomniano wcześniej, każdy z trzech cykli transgresji podejmuje inny, ważny temat w rozwoju osobistym. 


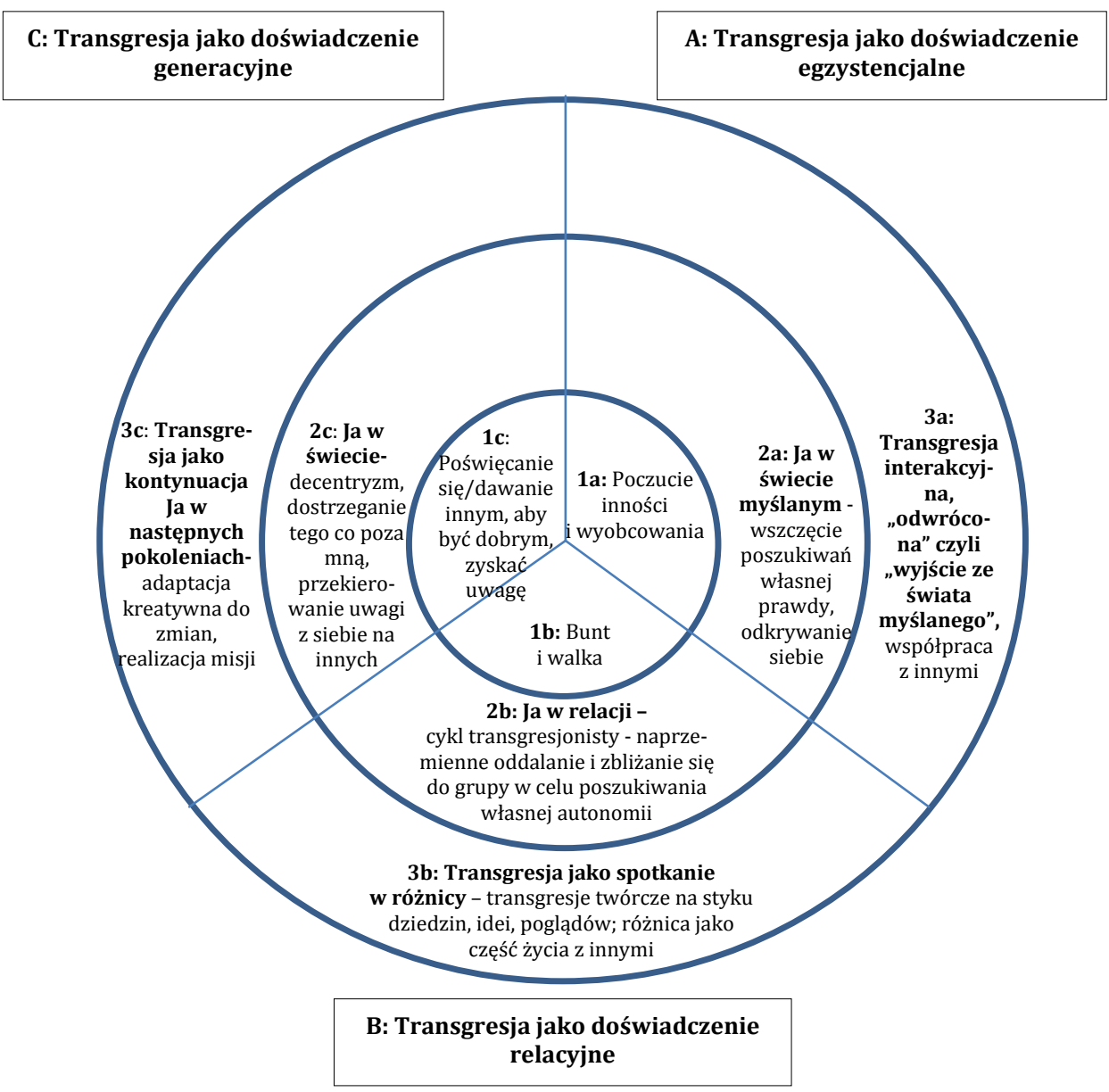

Rys. 2. Transgresja jako spiralny proces (samo)uczenia się - cykle doświadczeń transgresyjnych

Źródło: opracowanie na podstawie wyników badań własnych

Pierwszy cykl doświadczeń - A. Transgresja jako doświadczenie egzystencjalne - służy wykształceniu wewnętrznej integralności i synchronizacji z własnymi potrzebami. Kształtowanie orientacji transgresyjnej (1a) rozpoczyna się od poczucia inności i wyobcowania wśród innych. Transgresje przygotowawcze (2a) mają charakter introspekcyjny, zachodzą w „świecie myślanym” narratora, tzn. dotyczą poszukiwania własnej prawdy, poznawania siebie, przekraczania ograniczeń mentalnych w postaci przekonań o sobie i swoich możliwościach. Transgresje przygotowawcze $\mathrm{w}$ tym cyklu polegają na udowodnieniu sobie czegoś poprzez wielokrotne „zanurzenie się” w obcym, nowym, odmiennym kontekście w celu poznawania siebie za każdym razem od nowa, aktu ogarniania każdorazowo siebie Innego (Simmel 2007). Mają one charakter „mobilny”, tzn. dotyczą poszukiwania 
własnego miejsca w szerszym planie, co często związane jest ze zmianą przestrzeni fizycznej i zawodowej. Ten wątek biograficzny odzwierciedla „archetyp wędrowca” w ujęciu Carol S. Pearson (1995) lub „symbolicznej podróży” w ujęciu Lawrenca Elsbreego (1982). W narracjach przejawia się on w postaci podróży intelektualnej lub/i fizycznej, np. w postaci: cyklicznych zmian miejsca życia lub/i pracy (co ok. 3-5 lat), zmiany charakteru pracy, zmiany zespołu współpracowników czy ludzi wokół siebie. Przekraczanie granic swoich możliwości i sprawdzanie się w często zmieniającym się kontekście życia wymaga dużej koncentracji na sobie lub/i pracy zawodowej, co doprowadza w poszczególnych przypadkach do świadomej rezygnacji z posiadania własnej rodziny i inwestowania energii w życie rodzinne na tym etapie rozwoju osobistego. Słuchając opowieści narratorów, można odnieść wrażenie, że przygotowawcze „transgresje mobilne” nasycają się i kończą jako mechanizm stymulujący rozwój w momencie, gdy sprawca transgresji zaczyna wreszcie doświadczać swoistej ciągłości Ja i wewnętrznej stabilności pomimo wielokrotnej zmiany kontekstu życia oraz kiedy rozpoznaje własny repertuar narzędzi aktywności transgresyjnej. Innymi słowy, kiedy zaczyna rozpoznawać siebie jako tę samą osobę i mieć zaufanie do swoich możliwości, pomimo zmiany miejsc, aktywności, rodzaju podejmowanych zadań i ludzi wokół siebie. Ten etap procesu dojrzewania stanowi przełom w biografii, ponieważ sprawca transgresji wreszcie zatrzymuje się w wybranym przez siebie miejscu docelowym, w którym widzi możliwości wykorzystania swojej wiedzy i sprawczości, a następnie zaczyna realizować transgresję kluczową w biografii zawodowej (3a), tj. zadanie, projekt, z którego jest znany i rozpoznawany $\mathrm{w}$ środowisku zawodowym. W tym cyklu jest to transgresja o charakterze interakcyjnym, w której sprawca przekracza swój „świat myślany” - świat idei i wyobrażeń umiejscowiony w świecie bez granic. Transgresja jest tu „rozpoznawaniem swoich możliwości” i realizacją założonego scenariusza transgresyjnego w działaniu po drugiej stronie, tj. w świecie społecznym, który funkcjonuje dzięki granicom. Sprawca, przekraczając swój świat idei, w rzeczywistym miejscu i z realnymi ludźmi dokonuje czynów prawdziwie pedagogicznych, w których granice przekracza nie tylko on sam, ale przede wszystkim odbiorcy jego działań. Sprawcami tego typu transgresji są pedagodzy realizujący innowacyjne projekty dydaktyczne, w których to odbiorcy ich działań (dzieci, młodzież, szkoła, środowisko lokalne) rozwijają swój charakter i umysł, wzbogacają osobiste doświadczenia, przekraczają bądź poszerzają granice własnych możliwości.

Co ciekawe, po zakończeniu danego projektu/zadania, charakterystyczny w tym cyklu transgresji jest ponowny powrót sprawcy do „świata myślanego” i tworzenie nowej wizji transgresyjnej, powtórnie w oderwaniu od ograniczeń świata zewnętrznego. Ten powrót jest istotą transgresji, którą określiłam jako „odwróconą", ponieważ sprawca pokonuje granice w drugą stronę - od świata zewnętrznego ku sobie do „świata myślanego”. Być może ta umiejętność odzyskiwania dystansu do rzeczywistości poprzez powrót do wewnętrznego świata idei daje niegasnącą motywację i niczym niezmąconą oryginalność myślenia i działania 
w twórczym przekraczaniu granic. Praca ze sprawcami będącymi w tym cyklu transgresji bywa z tego powodu ekscytująca, ale i trudna. Są to osoby o bardzo niestandardowych i oryginalnych pomysłach, często spostrzeganych jako nierealne i utopijne w środowisku, np. wśród współpracowników, w zespole projektowym czy dla osób zapraszanych do działań, często niewierzących w powodzenie zadania. W opisie tych doświadczeń transgresyjnych dominują sformułowania będące przejawem twórczego myślenia pytajnego, wyrażające się we wrażliwości na to, co dzieje się dookoła; dostrzeganiu problemów i poszukiwaniu rozwiązań, których inni nie widzą; gotowości i chęci aktywnego poszukiwania informacji, nowych miejsc, przeżyć i ludzi; stawianiu odkrywczych pytań sobie i innym.

Drugi cykl doświadczeń transgresyjnych - B. Transgresja jako doświadczenie relacyjne - podejmuje temat rozwoju osobistego w kontekście przyglądania się sobie, ale w relacji z innymi i kształtowania na tym tle własnej autonomii. Transgresje te mają również charakter psychologiczny, ale dokonują się już nie w wewnętrznym świecie wyobrażeń o sobie (jak w Cyklu A), ale na tle relacji i odmienności tego, jak każdy z nas może inaczej doświadczać tego samego świata - ja $v s$ inni. Kształtowanie orientacji transgresyjnej (1b) rozpoczyna się od okresu buntu i walki z innymi, których celem jest zwyciężenie za wszelką cenę, czasami kosztem własnego dobra. Wykształcona w cyklu A wewnętrzna integralność ponownie zostaje rozbita w cyklu B na skutek „spotkania się w różnicy” ze światem społecznym, w którym osoba zaczyna realizować ważne dla siebie przedsięwzięcia życiowe i zawodowe. Kształtowanie orientacji transgresyjnej przejawia się w przekraczaniu ograniczeń, które narzuca środowisko. To oznacza, że transgresjonista zna siebie, jest już świadomy własnej kompetencji oraz tego, czego jest w stanie dokonać, ale okazuje się to niemożliwe w wyniku napotkanych barier, np. w postaci odmiennego światopoglądu czy systemu wartości ludzi z najbliższego otoczenia, czy ograniczeń formalnych o charakterze administracyjnym, prawnym, instytucjonalnym. Dlatego kolejny etap rozwoju, transgresje przygotowawcze (2b) mają charakter „emancypacyjny”, bo polegają na wyzwoleniu się spod ograniczeń nakładanych przez innych ludzi, oraz „aksjologiczny”, bo mają doprowadzić do krystalizacji własnych przekonań i wartości. Transgresjonista już nie chce „wyprawiać się w podróż” i szukać bardziej odpowiedniego miejsca dla siebie, jak w poprzednim cyklu, ale chce zostać w danym miejscu i to właśnie w nim przekroczyć zastane granice. To wymaga od niego radzenia sobie $\mathrm{z}$ niewygodą $\mathrm{w}$ relacji $\mathrm{w}$ postaci: konfrontacji, ścierania się, walki, doświadczania zawodów czy samotności w uprawianej twórczości, prezentowanych poglądach i wartościach. Przygotowawcze „transgresje emancypacyjne” i „aksjologiczne” (2b) kształtują umiejętność dystansowania się do rzeczywistości i zachodzą w postaci naprzemiennego „oddalania i zbliżania się” do wspólnoty, np. społeczności zawodowej, w celu negocjowania z samym sobą i podjęcia walki o to, w co transgresjonista wierzy i co ma wartość dla niego, a co dla innych. Stąd nieodzowne stają się okresowe ucieczki od środowiska (np. zawodowego) w celu nabrania gotowości i odwagi do dokonania transgresji kluczowych, przyjęcia 
wygranej, ale też godzenia się ze stratą (np. rozejście się z osobami znaczącymi/autorytetami, utrata współpracowników). Ucieczka może przejawiać się np. $\mathrm{w}$ rezygnacji $\mathrm{z}$ pracy i uprawianego zawodu na 10 lat, a następnie powrocie do niego z pełną świadomością i planem na to, jak zrealizować to, w co sprawca wierzy. Może mieć także charakter „ucieczki wewnętrznej” w postaci wycofania się emocjonalnego i przejściowej utraty wiary we własną pracę. Transgresja kluczowa (3b) zachodzi poprzez konfrontację w relacji ze środowiskiem, ale już nie na zasadzie buntu i opozycji, ale „spotkania się w różnicy” i wykorzystania tej różnicy jako wartościowego zasobu w swojej aktywności zawodowej. Być może dlatego transgresje kluczowe w tym cyklu odbywają się poprzez twórczy mechanizm bisocjacji, czyli łączenia różnych stanowisk i podejść, w celu poszukiwania odkrywczych rozwiązań nietypowych sytuacji. Są to najczęściej projekty edukacyjne lub twórczość naukowa rodząca się na styku dwóch odmiennych dziedzin, poglądów i idei.

Trzeci cykl doświadczeń transgresyjnych - C. Transgresja jako doświadczenie generacyjne - dotyczy potrzeby bycia częścią czegoś większego i troski o dobro wspólne. Bazą jest tutaj odwaga zdobyta w poprzednim cyklu B, który ugruntowuje sprawcę w wolności indywidualnej i autonomii oraz w przekonaniu, że można iść ze swoimi osiągnięciami dalej i pokazać je światu, bo są tego warte. Kształtowanie orientacji transgresyjnej (1c) w tym cyklu polega na przekraczaniu granic postawy egocentrycznej, która na początku przejawia się w narracjach badanych w postaci czynienia dobra dla innych w celu uzyskania uwagi i docenienia własnej osoby. Dlatego transgresje przygotowawcze (2c) polegają na przejściu od silnej koncentracji na sobie w relacji z innymi do postawy „decentryzmu” (Torrance, Safter 1999; Millar 2004), czyli dostrzegania tego, co poza mną. Transgresje kluczowe (3c) w tym cyklu mają dać sprawcy możliwość kontynuacji Ja w następnych pokoleniach, twórczej adaptacji do zmieniającej się rzeczywistości (vs próby utrzymania starego porządku w obawie przed podjęciem ryzyka, utratą ważnego miejsca w grupie, środowisku zawodowym). Przekraczanie granic w tym cyklu ma charakter generacyjny i jest ściśle związane z kategorią czasu, bo przejawia się w chęci pozostawienia po sobie czegoś, co przetrwa i w co sprawca transgresji wierzy, bo dzięki temu może szerzyć dobro w postaci własnych idei, wiedzy i dokonań. Transgresje kluczowe mają charakter „prognostyczny”. Orientacja sprawcy jest prospektywna, zakłada nie tyle przystosowanie się do zastanych realiów i działanie w odpowiedzi na aktualnie doświadczane granice (w edukacji), ale „adaptację kreatywną" (Kozielecki 1987), czyli wbudowywanie mądrych innowacji do przyszłego świata. Aby osiągnąć powyższe cele, sprawcy wykorzystują takie strategie transgresyjne, jak: mechanizmy antycypacji twórczej, myślenie perspektywiczne i diagnozę probabilistyczną. Projekty transgresyjne są często wynikiem twórczych transformacji (Szmidt 2013), czyli modyfikowania i przekształcania zastanej formy, dalekosiężnego redefiniowania wyobrażeń na temat rzeczywistości szkolnej, poszukiwania nowości oraz inspirowania się elementami nowymi, pozornie niepasu- 
jącymi, a następnie ich asymilowaniem do edukacji. Stąd transgresje kluczowe w biografiach sprawców przybierają postać wdrażanych do praktyki edukacyjnej, wysoce innowacyjnych scenariuszy i trendów edukacyjnych, spotykających się $\mathrm{z}$ dużym oporem i niezrozumieniem środowiska. Sprawcy transgresji w tym cyklu tworzą swoje projekty w odpowiedzi na sytuacje prognozowane, np. na rok 2050, będące udziałem przyszłych pokoleń. Przykład stanowią autorskie szkoły czy alternatywne programy i procedury nauczania, tworzone z myślą o przyszłości zawodowej aktualnego pokolenia młodzieży oraz przyszłych pokoleń, którym obecny system edukacji nie proponuje niczego rozwojowego.

Można postawić hipotezę, że ten typ transgresji kluczowej może bardziej niż pozostałe przyjmować postać transgresji historycznej, kiedy to jej sprawca przekracza granice, których nikt dotychczas nie przekroczył, robi coś nowego i dobrego dla ogółu ludzkości. Są to moim zdaniem transgresje o największym stopniu nowości i oryginalności. Wartościowość tych projektów jest natomiast szeroko dyskutowana w środowisku ze względu na charakterystyczny „przeskok w czasie” i niezrozumienie wśród osób myślących aktualnymi standardami i schematami.

\section{Podsumowanie}

Zaprezentowany model pokazuje kolejność (Cykle A, B, C) oraz skalę doświadczeń transgresyjnych (kształtowanie orientacji transgresyjnej - transgresje przygotowawcze - transgresje kluczowe). Oczywiście rozwój człowieka rzadko jest tak klarowny i uporządkowany jak w przedstawionym opisie. Opracowany model może być jednak pomocny $\mathrm{w}$ rozwoju osobistym i autorefleksji na temat sposobu doświadczania trudności i granic. Może być również wykorzystany do weryfikacji empirycznej $\mathrm{w}$ przyszłych badaniach nad innowatorami nie tylko $\mathrm{w}$ dziedzinie edukacji. Ten cykl lub poziom, na którym się odnajdujemy w diagramie, może świadczyć o tym, że głównie w nim przebywamy. Wkroczenie na kolejny etap cyklu lub o poziom wyżej wskazuje na poszerzenie repertuaru reakcji i możliwości wyboru zachowań w odpowiedzi na ograniczenia, których doświadczamy. Innymi słowy świadomość tego, gdzie się znajdujemy, może pomóc pójść dalej.

\section{Bibliografia}

Baranowicz K. (2000) Pedagogika alternatywna. Dylematy praktyki, Kraków, Oficyna Wydawnicza „Impuls”.

Chmielińska A. (2017) Dynamika transgresji twórczych. Studia przypadków pedagogów, Łódź, Wydawnictwo UŁ. 
Dauber H. (1997) Obszary uczenia się w przyszłości. Perspektywy pedagogiki humanistycznej, Kraków, Oficyna Wydawnicza „Impuls”.

Elsbree L. (1982) The Rituals of Life. Patterns in Narrativies, Port Washington, New York, Kennikat Press.

Figiel M. (2001) Szkoły autorskie w Polsce. Realizacje edukacyjnych utopii, Kraków, Oficyna Wydawnicza „Impuls”.

Galewska-Kustra M. (2009) Studium przypadku w pedagogicznych badaniach nad twórczością. W poszukiwaniu praktycznych zastosowań metody w: Metody pedagogicznych badań nad twórczością. Teoria i empiria, K. J. Szmidt (red.), Łódź, Wydawnictwo AHE.

Kamiński A. (1970) Metoda, technika, procedura badawcza w pedagogice empirycznej w: Metodologia pedagogiki społecznej, R. Wroczyński, T. Pilch (red.), Wrocław, Ossolineum.

Kaufmann J. C. (2010) Wywiad rozumiejący, Warszawa, Oficyna Naukowa.

Konarzewski K. (2000) Jak uprawiać badania oświatowe. Metodologia praktyczna, Warszawa, Wydawnictwo Naukowe PWN.

Kozielecki J. (1987) Koncepcja transgresyjna człowieka. Analiza psychologiczna, Warszawa, PWN.

Kozielecki J. (1992) Myślenie i rozwiq̨zywanie problemów w: Psychologia ogólna, T. Tomaszewski (red.), Warszawa, PWN.

Kozielecki J. (1996) Człowiek wielowymiarowy, Warszawa, Wydawnictwo Akademickie „Żak”.

Kozielecki J. (1997) Transgresja i kultura, Warszawa, Wydawnictwo Akademickie „Żak”.

Kozielecki J. (2001) Psychotransgresjonizm. Nowy kierunek psychologii, Warszawa, Wydawnictwo Akademickie „Żak”.

Kozielecki J. (2004) Społeczeństwo transgresyjne. Szansa i ryzyko, Warszawa, Wydawnictwo Akademickie „Żak”.

Kozielecki J. (2007) Psychotransgresjonizm. Nowy kierunek psychologii, Warszawa, Wydawnictwo Akademickie „Żak”.

Kozielecki J. (2008) Psychologia w wielkim świecie, Warszawa, Wydawnictwo Akademickie „Żak”. 
Kozielecki J. (2009) Psychotransgresjonizm - zarys nowego paradygmatu w: Nowe idee w psychologii, J. Kozielecki (red.), Gdańsk, Gdańskie Wydawnictwo Psychologiczne.

Łobocki M. (2006) Metody i techniki badań pedagogicznych, Kraków, Oficyna Wydawnicza „Impuls”.

Merriam S. B. (1998) Qualitative Research and Case Study Applications in England, San Francisco, Jossey-Bass Publishers.

Miles M. B., Huberman A. M. (2000) Analiza danych jakościowych, Białystok, Wydawnictwo Uniwersyteckie Trans Humana.

Millar G. W. (2004) The Making of a Beyonder. Ways to Nurture Your Creative Achievement and Spirit. A Detailed Discussion of the Characteristics That Make an Individual a Beyonder, Bensenville, Scholastic Testing Service.

Pearson C. S. (1995) Nasz wewnętrzny bohater, czyli sześć archetypów według których żyjemy, Poznań, Dom Wydawniczy Rebis.

Peterson C., Seligman M. (2004) Character Strengths and Virtues: A Handbook and Classification, Washington, American Psychological Association.

Petty G. (2010) Nowoczesne nauczanie, Gdańsk, Gdańskie Wydawnictwo Psychologiczne.

Pilch T., Bauman T. (2001) Zasady badań pedagogicznych. Strategie jakościowe i ilościowe, Warszawa, Wydawnictwo Akademickie „Żak”.

Przyborowska B. (2003) Struktury innowacyjne w edukacji. Teoria - praktyka - rozwój, Toruń, Wydawnictwo UMK.

Schulz R. (1989) Nauczyciel jako innowator, Warszawa, Wydawnictwa Szkolne i Pedagogiczne.

Schulz R. (1990) Twórczość. Społeczne aspekty zjawiska, Warszawa, PWN.

Schulz R. (1994) Twórczość pedagogiczna. Elementy teorii i badań, Warszawa, Instytut Badań Edukacyjnych.

Simmel G. (1975) Socjologia, Warszawa, PWN.

Simmel G. (1997) Filozofia pieniądza, Poznań, Wydawnictwo Fundacji Humaniora.

Simmel G. (2006) Most i drzwi. Wybór esejów, Warszawa, Oficyna Naukowa. 
Simmel G. (2007) Filozofia życia. Cztery rozdziały metafizyczne, Warszawa, Wydawnictwo IFiS.

Szmidt K. J. (2013) Pedagogika twórczości, Sopot, Gdańskie Wydawnictwo Psychologiczne.

Stake R. (2009) Jakościowe studium przypadku w: Metody badan jakościowych, t. 1, D. Norman, Y. Lincoln (red.), Warszawa, Wydawnictwo Naukowe PWN.

Studenski R. (2004) Ryzyko i ryzykowanie, Katowice, Wydawnictwo UŚ.

Studenski R. (2006) Skłonność do ryzyka a zachowania transgresyjne w: Psychologia zachowań ryzykownych. Koncepcja badania praktyka, M. Goszczyńska (red.), Warszawa, Wydawnictwo Akademickie „Żak”.

Torrance E. P., Safter H. T. (1999) Making the Creative Leap Beyond..., Buffalo, New York, Creative Education Foundation Press.

Turlejska B. (1998) Monografia pedagogiczna i studium przypadku w: Orientacje w metodologii badań pedagogicznych, S. Palka (red.), Kraków, Wydawnictwo UJ.

Yin R. K. (2003) Case Study Research. Design and Methods, California, SAGE Publications, Thousand Oaks. 